\title{
Metoda Rezolucji i Tablice Analityczne w Symbolic Logic Lewisa Carrolla
}

\author{
Resolution and Analytic Tableaux \\ in Lewis Carroll's Symbolic Logic
}

\author{
Jerzy Pogonowski \\ Institute of Linguistics, Adam Mickiewicz University \\ ul. Aleja Niepodległości 4, 61-874 Poznań, POLAND \\ pogoneamu.edu.pl
}

\begin{abstract}
We discuss Lewis Carroll's invention of the rule of resolution and his prototype of the analytic tableaux method from 1896. A few examples are analyzed and a modest open problem is formulated. We conclude the paper with some metalogical and historical remarks. ${ }^{1}$
\end{abstract}

Reguła rezolucji była stosowana już w XIX wieku, choć pod inną nazwą niż obecnie i w odniesieniu jedynie do zdań kategorycznych określonej postaci. Wykorzystywał ją mianowicie CHARLES LUTWIDGE DODGSON, publikujący także pod pseudonimem LEWIS CARROLL. W jego podręczniku Symbolic Logic z 1896 roku metoda ta występuje pod nazwą the method of underscoring. W niniejszym tekście ograniczamy się do zaprezentowania działania tej metody w rozwiązywaniu sorytów (łańcuszników), a więc w poszukiwaniu konkluzji wynikającej z szeregu (co najmniej trzech) przesłanek. Pod uwagę brane są jedynie kategoryczne zdania ogólne, a więc zdania postaci Wszystkie $A$ sq $B$ lub Żadne A nie jest $B$. Zakładamy, że czytelnicy znają diagramy Carrolla oraz warunki prawdziwości zdań kategorycznych.

Chociaż Carroll sformułował poprawnie regułę rezolucji (dla języka zdań kategorycznych), to proponowane przez niego początkowo pewne ,usprawnienia” natury heurystycznej są błędne. Autor sam wykrył swoją pomyłkę i odkrycie to było, jak można sądzić, jednym z powodów, dla którego opracował ogólniejszą (i całkiem poprawną) metodę, nazywaną przez niego the method of trees $\mathrm{i}$ będącą prototypem metody tablic analitycznych, których systematyczne badania rozpoczęły się dopiero od lat pięćdziesiątych dwudziestego wieku (Beth, Kanger, Schütte, Hintikka, Smullyan, Jeffrey, Lis, i inni). Obecnie metoda tablic analitycznych, w wielu odmianach, jest powszechnie stosowana np. w systemach automatycznego dowodzenia twierdzeń (podobnie zresztą jak różne odmiany reguły rezolucji).

\footnotetext{
${ }^{1}$ An English summary of this paper has been published under the title Lewis Carroll's Resolution and Tableaux in the Festschrift dedicated to Professor Jerzy Perzanowski (Janusz Sytnik-Czetwertyński (ed.), Wydawnictwo Uniwersytetu Jagiellońskiego, Kraków 2009, 73-92).
} 


\section{Reguła rezolucji (dla zdań kategorycznych ogólnych)}

Używamy standardowej notacji z rachunku zbiorów. $A^{\prime}$ jest dopełnieniem $A$ (w ustalonym uniwersum $U$ ). Przypomnijmy, że $A \subseteq B$ jest równoważne z $A \cap B^{\prime}=\emptyset$. Dla dowolnych zbiorów $A, B$ oraz $C$ zachodzi:

$$
(\star) \quad\left(A \cap C=\emptyset \wedge B \cap C^{\prime}=\emptyset\right) \rightarrow A \cap B=\emptyset .
$$

DowóD.

$$
\begin{array}{rll}
\text { 1. } & A \cap C=\emptyset & \text { założenie } \\
\text { 2. } & B \cap C^{\prime}=\emptyset & \text { założenie } \\
\text { 3. } & (A \cap C) \cup C^{\prime}=C^{\prime} & \cup C^{\prime} \text { do obu stron } \\
\text { 4. } & \left(B \cap C^{\prime}\right) \cup C=C & \cup C \text { do obu stron } \\
\text { 5. } & \left(A \cup C^{\prime}\right) \cap\left(C \cup C^{\prime}\right)=C^{\prime} & 3 \text {, rachunek } \\
\text { 6. } & (B \cup C) \cap\left(C \cup C^{\prime}\right)=C & 4, \text { rachunek } \\
\text { 7. } & A \cup C^{\prime}=C^{\prime} & \text { bo } C \cup C^{\prime}=U \\
\text { 8. } & B \cup C=C & \text { bo } C \cup C^{\prime}=U \\
\text { 9. } & \left(A \cup C^{\prime}\right) \cap(B \cup C)=C \cap C^{\prime} & 7,8 \cap \text { stronami } \\
\text { 10. } & \left(A \cup C^{\prime}\right) \cap(B \cup C)=\emptyset & \text { bo } C \cap C^{\prime}=\emptyset \\
\text { 11. } & (A \cap B) \cup\left(B \cap C^{\prime}\right) \cup(A \cap C) \cup\left(C \cap C^{\prime}\right)=\emptyset & 10, \text { rachunek } \\
\text { 12. } & A \cap B=\emptyset & 11,1,2, C \cap C^{\prime}=\emptyset .
\end{array}
$$

Q.E.D.

(oczywiście można też prościej, przy użyciu rachunku kwantyfikatorów, ale ta metoda była Carrollowi niedostępna).

Ćwiczenie: zaznacz na diagramie Carrolla sytuację wyrażaną przez przesłanki. Jaką informację o zależnościach między zbiorami $A, B$ oraz $C$ można wtedy uzyskać z tego diagramu?

Wzór ( $\star$ ) jest całkiem oczywisty: poprzednik implikacji ( $\star$ ) głosi, że $A \subseteq C^{\prime}$ oraz $B \subseteq C$. Powyższy dowód nie pochodzi on od Lewisa Carrolla, podany tu został dla zabawy algebrą zbiorów.

Wzór $(\star)$ to poprawne sformułowanie reguły rezolucji w języku algebry zbiorów.

\subsection{Reguły heurystyczne}

Początkowo Lewis Carroll uważał, że te wiadomości wystarczą, aby znaleźć konkluzję dla wszystkich ciągów ogólnych zdań kategorycznych, zawierających różne nazwy ogólne. Jeśli w takim ciągu nazwa $X$ występuje zarówno pozytywnie (niezaprzeczona), jak i negatywnie (z negacja przynazwową), to na mocy $(\star)$ może zostać wyeliminowana: nie wystąpi w konkluzji. Pozostałe nazwy w konkluzji wystąpią. W terminologii używanej przez Carrolla pierwsze z nich nazywane są eliminands, drugie retinends.

Szukanie konkluzji dla ciągu $\alpha_{1}, \alpha_{2}, \ldots, \alpha_{n}$ ogólnych zdań kategorycznych sprowadza się, pisze Carroll, do wykonania następujących czynności:

- (1) wyrażenia wszystkich zdań $\alpha_{i}$ w postaci zdań ogólno-przeczących, tj. zastąpienia zdań ogólno-twierdzących, jeśli takie występują, przez ogólno-przeczące z wykorzystaniem faktu, że:

$$
A \subseteq B \text { jest równoważne } \mathrm{z} A \cap B^{\prime}=\emptyset ;
$$

- (2) sporządzenia wykazu (w terminologii Carrolla: the register of attributes), które nazwy występują w których przesłankach w formie:

- (a) pozytywnej

- (b) negatywnej; 
- (3) ustawienia wszystkich przesłanek ciągu $\alpha_{1}, \alpha_{2}, \ldots, \alpha_{n}$ w takiej kolejności, aby dla pary następujących po sobie zdań można było zastosować regułę ( $\star$ ) eliminacji nazw;

- (4) stosowaniu reguły $(\star)$ tak długo, aż zostaną wyeliminowane wszystkie nazwy występujące w zdaniach ciągu $\alpha_{1}, \alpha_{2}, \ldots, \alpha_{n}$ zarówno pozytywnie, jak i negatywnie;

- (5) sformułowaniu konkluzji otrzymanej w wyniku tej procedury. Konkluzja będzie miała postać zdania ogólno-przeczącego. Można je przekształcić, jeśli wymagają tego względy stylistyczne, na zdanie ogólno-twierdzące, posługując się wspomnianą w punkcie (1) równoważnością.

Uwaga 1. Postać konkluzji jest sugerowana przez wykaz z punktu (2). Krok (3) nie jest oczywiście konieczny, ale jego wykonanie upraszcza dowody (co najmniej wizualnie). Carroll stosował ten krok w związku ze swoją metodą underscoring: podkreślania (pojedynczo i podwójnie) kolejno eliminowanych nazw.

Uwaga 2. Carroll przyjmował założenie (existential import), głoszące, że podmiot zdania ogólnotwierdzącego jest nazwą niepustą.

Uwaga 3. Heurystyczne wskazówki, podane wyżej w punktach (1)-(5) nie sq poprawnym algorytmem uzyskiwania konkluzji wynikającej logicznie z przesłanek. W wielu przypadkach pozwalaja uprościć pracę, ale — jak zobaczymy za chwilę — nie dostarczają ogólnej poprawnej metody.

Ogólniejsza od omówionej metody (i całkowicie poprawna!) jest metoda nie wprost, której Carroll także używał, pod nazwą the method of trees, polegająca na przyjęciu przypuszczenia, że konkluzja jest fałszywa i pokazaniu, że przypuszczenie to prowadzi do sprzeczności (zob. przykłady 7.-8. poniżej). To właśnie jest prototyp metody tablic analitycznych, opracowany przez Lewisa Carrolla ponad pół wieku przed „oficjalnymi”, systematycznymi badaniami tej metody.

\subsection{Notacja algebraiczna Carrolla}

Lewis Carroll wymyślił oryginalną notację algebraiczną, która pozwalała zapisywać dowody rezolucyjne w zwięzłej i przejrzystej postaci. Na początek:

- piszemy $X_{0}$ dla $X=\emptyset, X_{1}$ dla $X \neq \emptyset$;

- piszemy $X Y_{0}$ dla $X \cap Y=\emptyset, X Y_{1}$ dla $X \cap Y \neq \emptyset$ (i podobnie dla iloczynów większej liczby zbiorów);

- używamy symbolu $\dagger$ dla koniunkcji, a symbolu 9 w przypadku, gdy prawdziwość przesłanek pociąga za sobą prawdziwość konkluzji. Tak więc, np.

$$
X M_{0} \dagger Y M_{0}^{\prime} \Phi X Y_{0}
$$

oznacza, że prawdziwość przesłanek $X M_{0}$ oraz $Y M_{0}^{\prime}$ implikuje prawdziwość wniosku $X Y_{0}$.

Wyrażenie postaci $X Y_{0}$ jest nazywane nullity (i podobnie dla pustych iloczynów większej liczby zbiorów).

Wyrażenie postaci $X Y_{1}$ jest nazywane entity (i podobnie dla niepustych iloczynów większej liczby zbiorów).

Oto niektóre z reguł sformułowanych przez Lewisa Carrolla (Symbolic Logic, 126):

- Two Nullities, with Unlike Eliminands, yield a Nullity, in which both Retinends keep their Signs. A Retinend, asserted in the Premisses to exist, may be so asserted in the Conclusion.

$$
X M_{0} \dagger Y M_{0}^{\prime} \boldsymbol{\Phi} X Y_{0}
$$


- A Nullity and an Entity, with Like Eliminands, yield an Entity, in which the Nullity-Retinend changes its Sign.

$$
X M_{0} \dagger Y M_{1} \llbracket X^{\prime} Y_{1}
$$

- Two Nullities, with Like Eliminands asserted to exist, yield an Entity, in which both Retinends change their Signs.

$$
X M_{0} \dagger Y M_{0} \dagger M_{1} \Phi X^{\prime} Y_{1}^{\prime}
$$

Rozpoznajemy w tych regułach znane prawa algebry zbiorów.

\section{3 ,The Method of Underscoring"}

Carroll zaznaczał stosowanie reguły $(\star)$ w swojej notacji w sposób następujący. Z założeń $X M_{0} \dagger Y M_{0}^{\prime}$ otrzymujemy, na mocy reguły $(\star)$ ) konkluzję $X Y_{0}$. Podkreślamy raz eliminand $M \mathrm{w}$ pierwszej przesłance oraz podkreślamy dwukrotnie eliminand $M^{\prime} \mathrm{w}$ przesłance drugiej. Te nazwy, które nie są podkreślone są retinends i tworzą wniosek $X Y_{0}$. Dla danego sorytu kontynuujemy tę procedurę dla wszystkich eliminands. Na końcu otrzymujemy nullity, które jest konkluzją rozważanego sorytu. Krótko: podkreślamy jednokrotnie pierwsze wystapienie każdego eliminand, a dwukrotnie drugie jego wystąpienie. To, co pozostaje niepodkreślone, to nullity, złożone z retinends, będące konkluzją.

Dla przykładu, dla przesłanek:

\begin{tabular}{|c|c|c|c|c|c|c|}
\hline 1 & 2 & 3 & 4 & 5 & 6 & 7 \\
\hline$K_{1} L_{0}^{\prime}$ & $D H_{0}^{\prime}$ & $A_{1} C_{0}$ & $B_{1} E_{0}^{\prime}$ & $K^{\prime} H_{0}$ & $B^{\prime} L_{0}$ & $D_{1}^{\prime} C_{0}^{\prime}$ \\
\hline
\end{tabular}

powyższa metoda daje:

\begin{tabular}{|c|c|c|c|c|c|c|c|c|}
\hline 1 & 5 & 2 & 6 & 4 & 7 & 3 & & \\
\hline$\underline{K} \underline{L}_{0}^{\prime}$ & $\underline{\underline{K^{\prime}}} \underline{\underline{H}}_{0}$ & $\underline{D} \underline{\underline{H}}_{0}^{\prime}$ & $\underline{B}^{\prime} \underline{\underline{L}}_{0}$ & $\underline{\underline{B}} E_{0}^{\prime}$ & $\underline{\underline{D}}_{1}^{\prime} \underline{C}_{0}^{\prime}$ & $A_{1} \underline{\underline{C}}_{0}$ & ๆ & $E^{\prime} A_{0} \dagger A_{1}$ \\
\hline
\end{tabular}

A zatem konkluzją 1.-7. jest: $A \cap E^{\prime}=\emptyset \wedge A \neq \emptyset$, czyli (existential import!): $A \subseteq E$.

\subsection{Ilustracja działania metody}

PRZYKŁAD 1. Rozważmy następujące siedem zdań kategorycznych, zapisanych w symbolice rachunku zbiorów:

1. $K \subseteq L$

2. $D \subseteq H$

3. $A \cap C=\emptyset$

4. $B \subseteq E$

5. $K^{\prime} \cap H=\emptyset$

6. $B^{\prime} \cap L=\emptyset$

7. $D^{\prime} \subseteq C$.

Przedstawiamy wszystkie zdania w postaci zdań ogólno-przeczących:
1. $K \cap L^{\prime}=\emptyset$
2. $D \cap H^{\prime}=\emptyset$
3. $A \cap C=\emptyset$
4. $B \cap E^{\prime}=\emptyset$
5. $K^{\prime} \cap H=\emptyset$
6. $B^{\prime} \cap L=\emptyset$
7. $D^{\prime} \cap C^{\prime}=\emptyset$. 
Sporządzamy wykaz, o którym mówi punkt (2) metody:

\begin{tabular}{|l|c|c|c|c|c|c|c|c|}
\hline Nazwa: & $A$ & $B$ & $C$ & $D$ & $E$ & $H$ & $K$ & $L$ \\
\hline Pozytywnie: & 3 & 4 & 3 & 2 & & 5 & 1 & 6 \\
\hline Negatywnie: & & 6 & 7 & 7 & 4 & 2 & 5 & 1 \\
\hline
\end{tabular}

$\mathrm{Z}$ tego wykazu widać, że nazwy: $B, C, D, H, K$ oraz $L$ zostaną wyeliminowane. Tabela sugeruje nadto, że konkluzja powinna mieć postać $A \cap E^{\prime}=\emptyset$.

Ustawiamy powyższe zdania tak, aby do kolejno następujących po sobie stosować można było regułę $(\star)$ :

1. $K \cap L^{\prime}=\emptyset$

5. $K^{\prime} \cap H=\emptyset$

2. $D \cap H^{\prime}=\emptyset$

6. $B^{\prime} \cap L=\emptyset$

4. $B \cap E^{\prime}=\emptyset$

7. $D^{\prime} \cap C^{\prime}=\emptyset$

3. $A \cap C=\emptyset$.

Budujemy z tych przesłanek Dowód REZOLUCYJNY dla uzasadnienia konkluzji $A \cap E^{\prime}=\emptyset$ :

$\begin{array}{rll}\text { 1. } & K \cap L^{\prime}=\emptyset & \text { przesłanka } \\ \text { 5. } & K^{\prime} \cap H=\emptyset & \text { przesłanka } \\ \text { 2. } & D \cap H^{\prime}=\emptyset & \text { przesłanka } \\ \text { 6. } & B^{\prime} \cap L=\emptyset & \text { przesłanka } \\ \text { 4. } & B \cap E^{\prime}=\emptyset & \text { przesłanka } \\ \text { 7. } & D^{\prime} \cap C^{\prime}=\emptyset & \text { przesłanka } \\ \text { 3. } & A \cap C=\emptyset & \text { przesłanka } \\ \text { 10. } & L^{\prime} \cap H=\emptyset & (\star): 1 \text { i } 5, K \\ \text { 11. } & D \cap L^{\prime}=\emptyset & (\star): 10 \text { i } 2, H \\ \text { 12. } & B^{\prime} \cap D=\emptyset & (\star): 11 \text { i } 6, L \\ \text { 13. } & E^{\prime} \cap D=\emptyset & (\star): 12 \text { i } 4, B \\ \text { 14. } & C^{\prime} \cap E^{\prime}=\emptyset & (\star): 13 \text { i } 7, D \\ \text { 15. } & A \cap E^{\prime}=\emptyset & (\star): 14 \text { i } 3, C .\end{array}$

W kolumnie uzasadnień zaznaczamy względem którego literału dokonuje się rezolucji.

Przedstawmy jeszcze powyższy dowód w postaci drzewa: 


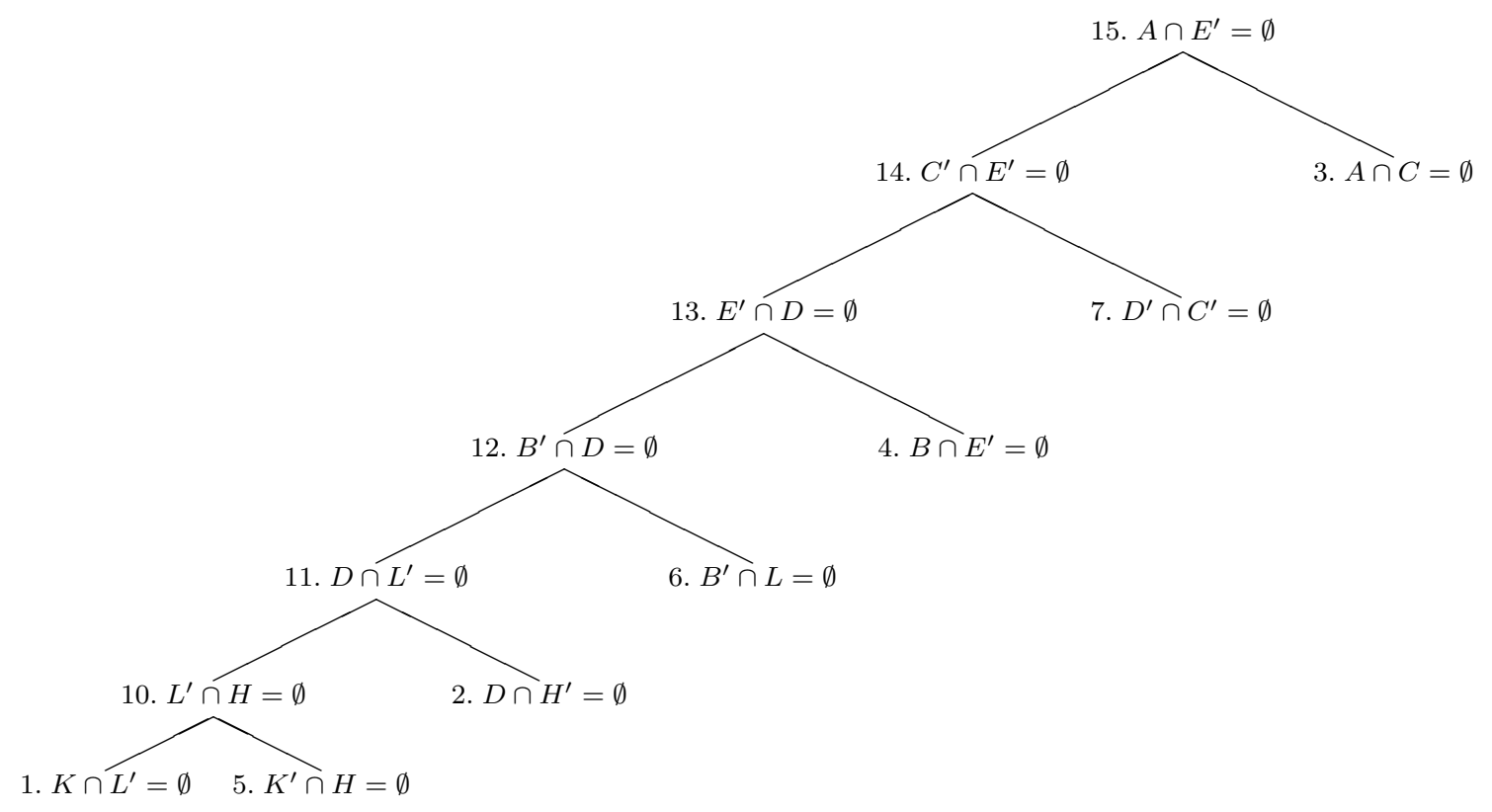

Jak widać, liśćmi tego drzewa są przesłanki, jego korzeniem konkluzja, a każdy wierzchołek nie będący liściem powstaje w wyniku zastosowania $(\star)$ do swoich bezpośrednich potomków.

PRZYKŁAD 2. Rozważmy następujące pięć zdań kategorycznych (w drugiej kolumnie) wraz z ich sprowadzeniami do zdań ogólno-przeczących (w trzeciej kolumnie):

\begin{tabular}{|l|l|l|}
\hline 1. & $A \subseteq B$ & $A \cap B^{\prime}=\emptyset$ \\
\hline 2. & $D \subseteq E$ & $D \cap E^{\prime}=\emptyset$ \\
\hline 3. & $H \cap B=\emptyset$ & $H \cap B=\emptyset$ \\
\hline 4. & $C \cap E=\emptyset$ & $C \cap E=\emptyset$ \\
\hline 5. & $D^{\prime} \subseteq A$ & $D^{\prime} \cap A^{\prime}=\emptyset$ \\
\hline
\end{tabular}

Uwaga 4. Zdanie $D^{\prime} \cap A^{\prime}=\emptyset$ jest równoważne zarówno z $D^{\prime} \subseteq A$, jak i z $A^{\prime} \subseteq D$, jak wiadomo z elementarnego rachunku zbiorów.

Budujemy tabelę występowania nazw w zdaniach 1.-5.:

\begin{tabular}{|r|l|l|}
\hline Nazwa & Pozytywnie & Negatywnie \\
\hline$A$ & 1 & 5 \\
\hline$B$ & 3 & 1 \\
\hline$C$ & 4 & \\
\hline$D$ & 2 & 5 \\
\hline$E$ & 4 & 2 \\
\hline$H$ & 3 & \\
\hline
\end{tabular}

Tabela sugeruje, że nazwy: $A, B, D$ oraz $E$ zostaną wyeliminowane i że wniosek powinien mieć postać: $C \cap H=\emptyset$. Budujemy dowód rezolucyjny:

\begin{tabular}{|l|l|l|}
\hline 1. & $A \cap B^{\prime}=\emptyset$ & przesłanka \\
\hline 2. & $D \cap E^{\prime}=\emptyset$ & przesłanka \\
\hline 3. & $H \cap B=\emptyset$ & przesłanka \\
\hline 4. & $C \cap E=\emptyset$ & przesłanka \\
\hline 5. & $D^{\prime} \cap A^{\prime}=\emptyset$ & przesłanka \\
\hline 6. & $A^{\prime} \cap E^{\prime}=\emptyset$ & $(\star): 2,5, D$ \\
\hline 7. & $B^{\prime} \cap E^{\prime}=\emptyset$ & $(\star): 1,6, A$ \\
\hline 8. & $B^{\prime} \cap C=\emptyset$ & $(\star): 4,7, E$ \\
\hline 9. & $C \cap H=\emptyset$ & $(\star): 3,8, B$ \\
\hline
\end{tabular}


Zbudujmy jeszcze drzewo dowodowe:

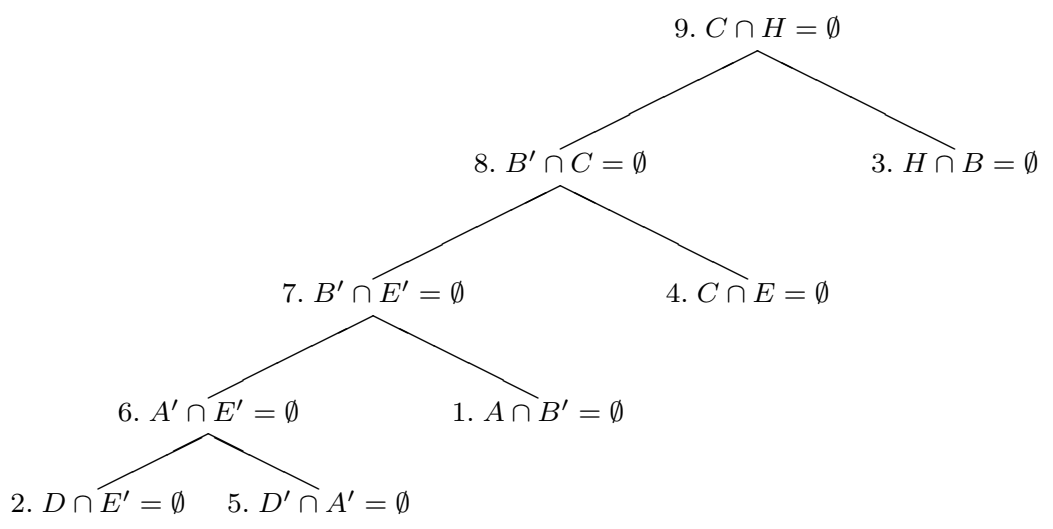

Zauważmy, że:

- dowód rezolucyjny można rozpocząć od dowolnej przesłanki;

- drzewa dowodowe (w rozważanych tu przypadkach) zawsze mają postać drzewa binarnego o powyższej „schludnej” postaci: są wyznaczone przez ciąg par $\left(C_{i}, A_{i}\right)(0 \leqslant i \leqslant n)$, gdzie $C_{0}$ oraz wszystkie $A_{i}$ są założeniami (przesłankami) lub elementami pewnej klauzuli $C_{j}$ dla $j<i$, a każda $C_{i+1}(i<n)$ jest rezolwentą $C_{i}$ oraz $A_{i}$. Tego typu rezolucja nazywana jest rezolucja liniowa.

\section{Lańcuszniki Carrolla}

Pobawimy się teraz w analizę niektórych łańcuszników podanych przez Carrolla, z zastosowaniem omówionej w części 1 metody. Pozostajemy przy języku oryginału. Najpierw rozważymy parę przykładów, w których heurystyczne wskazówki Carrolla dobrze się sprawdzają. Następnie pokażemy, że nie są one jednak w ogólności poprawne. Postawimy w związku z tym pewien problem z algebry zbiorów, który przekłada się na problem zakresu poprawności metody proponowanej przez Carrolla.

\subsection{Przykłady latwe}

\section{PrzykŁad 3. The Pigs and Ballons Problem.}

- 1. All, who neither dance on tight ropes nor eat penny-buns, are old.

- 2. Pigs, that are liable to giddiness, are treated with respect.

- 3. A wise balloonist takes an umbrella with him.

- 4. No one ought to lunch in public, who looks ridiculous and eats penny-buns.

- 5. Young creatures, who go up in balloons, are liable to giddiness.

- 6. Fat creatures, who look ridiculous, may lunch in public, provided they do not dance on tight ropes.

- 7. No wise creatures dance on tight ropes, if liable to giddiness.

- 8. A pig looks ridiculous, carrying an umbrella.

- 9. All, who do not dance on tight ropes, and who are treated with respect are fat.

Znajdujemy nazwy ogólne występujące w tych przesłankach: 


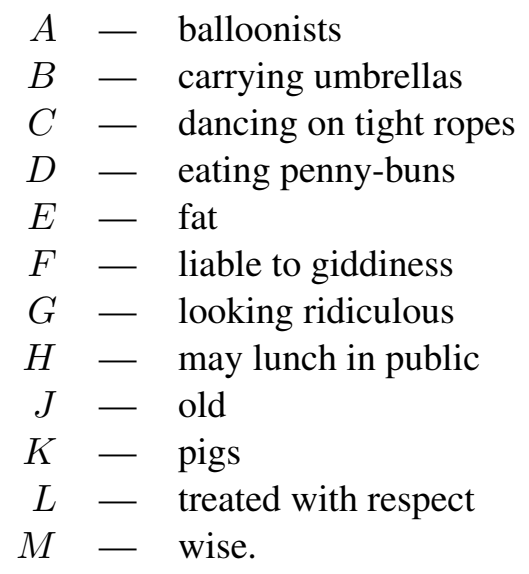

Przyjmiemy, za Carrollem, założenie, że young to tyle, co not old. Powyższe przesłanki mają następujące schematy (przekształcamy zdania ogólno-twierdzące na zdania ogólno-przeczące zgodnie z podaną wcześniej regułą):

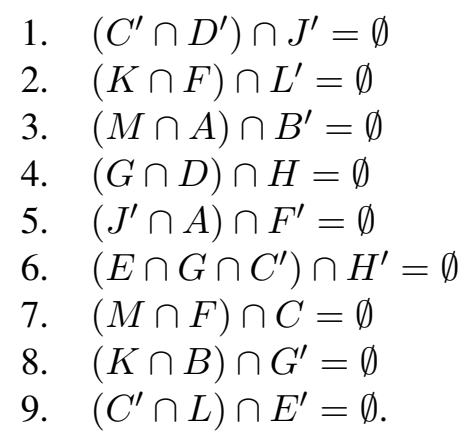

Zauważmy, że wszystkie te zdania mają złożone (z pomocą koniunkcji przynazwowej) podmioty. W dalszym ciągu będziemy opuszczać nawiasy w wieloczłonowych iloczynach.

Budujemy tabelę występowania nazw w poszczególnych przesłankach:

\begin{tabular}{|c|l|l|}
\hline Nazwa & Pozytywnie & Negatywnie \\
\hline$A$ & 3,5 & \\
\hline$B$ & 8 & 3 \\
\hline$C$ & 7 & $1,6,9$ \\
\hline$D$ & 4 & 1 \\
\hline$E$ & 6 & 9 \\
\hline$F$ & 2,7 & 5 \\
\hline$G$ & 4,6 & 8 \\
\hline$H$ & 4 & 6 \\
\hline$J$ & & 1,5 \\
\hline$K$ & 2,8 & \\
\hline$L$ & 9 & 2 \\
\hline$M$ & 3,7 & \\
\hline
\end{tabular}

Tabela sugeruje, że wniosek będzie miał postać: $K \cap M \cap A \cap J^{\prime}=\emptyset$.

Zanim podamy dowód rezolucyjny, że $K \cap M \cap A \cap J^{\prime}=\emptyset$ można otrzymać z przesłanek 1.-9., wspomnimy jeszcze, że Carroll zalecał określoną kolejność stosowania $(\star)$. Jeżeli mianowicie jakaś nazwa występuje jeden raz w pewnej przesłance $P$, a dopełnienie tej nazwy występuje w kilku innych przesłankach $Q_{1}, Q_{2}, \ldots, Q_{k}$, to przesłanki $Q_{1}, Q_{2}, \ldots, Q_{k}$ trzeba rozpatrzyć przed rozważeniem przesłanki $P$. Carroll pisał w takich przypadkach, że $P$ jest a premiss barred by $Q_{1}, Q_{2}, \ldots, Q_{k}$. $\mathrm{W}$ omawianym przykładzie mamy taką właśnie sytuację: 
- przesłankę 5 trzeba rozważyć przed przesłankami 2 i 7;

- przesłankę 7 trzeba rozważyć przed przesłankami 1, 6 oraz 9;

- przesłankę 8 trzeba rozważyć przed przesłankami 4 i 6.

Zrezygnujemy tym razem z wykonania zaleceń punktu (3). Poszczególne kroki dowodowe będą numerowane podwójnie: raz numerem bieżącym, a nadto (pogrubionym) numerem wykorzystywanej przesłanki oraz wyniku zastosowania $(\star)$. Budujemy dowód rezolucyjny:
1. 1. $C^{\prime} \cap D^{\prime} \cap J^{\prime}=\emptyset$
przesłanka
2. 4. $G \cap D \cap H=\emptyset$
3. 10. $C^{\prime} \cap J^{\prime} \cap G \cap H=\emptyset$
4. 6. $E \cap G \cap C^{\prime} \cap H^{\prime}=\emptyset$ przesłanka
5. 11. $C^{\prime} \cap J^{\prime} \cap G \cap E=\emptyset$
6. 8. $K \cap B \cap G^{\prime}=\emptyset$
( $\star \mathbf{1}) \mathbf{1}, \mathrm{4}, D$
przesłanka
7. 12. $C^{\prime} \cap J^{\prime} \cap E \cap K \cap B=\emptyset$
$(\star): \mathbf{6 , 1 0}, H$
8. 9. $C^{\prime} \cap L \cap E^{\prime}=\emptyset$
przesłanka
9. 13. $C^{\prime} \cap J^{\prime} \cap K \cap B \cap L=\emptyset$

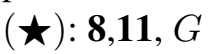
10. 7. $M \cap F \cap C=\emptyset$
przesłanka
11. 14. $J^{\prime} \cap K \cap B \cap L \cap M \cap F=\emptyset$
$(\star): \mathbf{9 , 1 2}, E$
12. 3. $M \cap A \cap B^{\prime}=\emptyset$
przesłanka
13. 15. $J^{\prime} \cap K \cap L \cap M \cap F \cap A=\emptyset$
14. 2. $K \cap F \cap L^{\prime}=\emptyset$

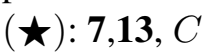
przesłanka
15. 16. $J^{\prime} \cap K \cap M \cap F \cap A=\emptyset$
$(\star): \mathbf{3 , 1 4}, B$
16. $\quad$ 5. $J^{\prime} \cap A \cap F^{\prime}=\emptyset$
przesłanka
17. 17. $J^{\prime} \cap K \cap M \cap A=\emptyset$
$(\star): \mathbf{2 , 1 5}, L$
przesłanka
$(\star): \mathbf{5}, \mathbf{1 6}, F$.

Zachęcamy do samodzielnego narysowania drzewa dowodowego.

Uwaga 5. Umowa notacyjna stosowana przez Carrolla pozwala na nieco krótsze przedstawienie powyższego dowodu (pomijamy wszędzie indeks ${ }_{0}$ ):

\begin{tabular}{|c|c|c|c|c|c|}
\hline $\begin{array}{l}. \\
2 . \\
3 . \\
4 . \\
5 .\end{array}$ & $\begin{array}{l}. \\
4 . \\
6 . \\
8 . \\
9 .\end{array}$ & 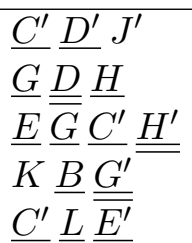 & $\begin{array}{r}6 . \\
7 . \\
8 . \\
9 . \\
10 .\end{array}$ & $\begin{array}{l}7 . \\
3 . \\
2 . \\
5 . \\
\therefore\end{array}$ & $\begin{array}{l}M \underline{F} \underline{\bar{C}} \\
M A \underline{\overline{B^{\prime}}} \\
K \underline{F} \underline{\overline{L^{\prime}}} \\
J^{\prime} A \underline{\overline{F^{\prime}}} \\
K M \overline{\bar{A}} J^{\prime}\end{array}$ \\
\hline
\end{tabular}

Istnieją też inne jeszcze konwencje notacyjne, pozwalające upraszczać tego typu dowody (zob. np. Crisler 1999).

Tak więc, wnioskiem z przesłanek 1.-9. jest $K \cap M \cap A \cap J^{\prime}=\emptyset$, co można odczytać np. jako: No wise young pigs go up in balloons.

PRZYKŁAD 4. Rozważmy następujące zdania kategoryczne:

- 1 . The only animals in this house are cats.

- 2. Every animal is suitable for a pet, that loves to gaze at the moon.

- 3. When I detest an animal, I avoid it.

- 4. No animals are carnivorous, unless they prowl at night.

- 5. No cat fails to kill mice. 
- 6. No animals ever take to me, except what are in this house.

- 7. Kangaroos are not suitable for pets.

- 8. None but carnivora kill mice.

- 9. I detest animals that do not take to me.

- 10. Animals, that prowl at night, always love to gaze at the moon.

Znajdujemy nazwy występujące w tych zdaniach:

$$
\begin{aligned}
& A \text { - avoided by me } \\
& B \text { - carnivora } \\
& C-\text { cats } \\
& D \text { - detested by me } \\
& E \quad \text { - in this house } \\
& H \text { - kangaroos } \\
& K-\text { killing mice } \\
& L \text { - loving to gaze at the moon } \\
& M \text { - prowling at night } \\
& N-\text { suitable for pets } \\
& R \text { - taking to me. }
\end{aligned}
$$

Znajdujemy schematy przesłanek:

$$
\begin{aligned}
\text { 1. } & E \cap C^{\prime}=\emptyset \\
\text { 2. } & L \cap N^{\prime}=\emptyset \\
\text { 3. } & D \cap A^{\prime}=\emptyset \\
\text { 4. } & M^{\prime} \cap B=\emptyset \\
\text { 5. } & C \cap K^{\prime}=\emptyset \\
\text { 6. } & E^{\prime} \cap R=\emptyset \\
\text { 7. } & H \cap N=\emptyset \\
\text { 8. } & B^{\prime} \cap K=\emptyset \\
\text { 9. } & R^{\prime} \cap D^{\prime}=\emptyset \\
\text { 10. } & M \cap L^{\prime}=\emptyset .
\end{aligned}
$$

Budujemy tabelę występowania nazw w przesłankach:

\begin{tabular}{|c|l|l|}
\hline Nazwa & Pozytywnie & Negatywnie \\
\hline$A$ & & 3 \\
\hline$B$ & 4 & 8 \\
\hline$C$ & 5 & 1 \\
\hline$D$ & 3 & 9 \\
\hline$E$ & 1 & 6 \\
\hline$H$ & 7 & \\
\hline$K$ & 8 & 5 \\
\hline$L$ & 2 & 10 \\
\hline$M$ & 10 & 4 \\
\hline$N$ & 7 & 2 \\
\hline$R$ & 6 & 9 \\
\hline
\end{tabular}

Tabela sugeruje, że wniosek będzie miał postać: $A^{\prime} \cap H=\emptyset$. Budujemy dowód rezolucyjny: 


\begin{tabular}{|r|l|l|}
\hline 1. & $E \cap C^{\prime}=\emptyset$ & przesłanka \\
\hline 2. & $L \cap N^{\prime}=\emptyset$ & przesłanka \\
\hline 3. & $D \cap A^{\prime}=\emptyset$ & przesłanka \\
\hline 4. & $M^{\prime} \cap B=\emptyset$ & przesłanka \\
\hline 5. & $C \cap K^{\prime}=\emptyset$ & przesłanka \\
\hline 6. & $E^{\prime} \cap R=\emptyset$ & przesłanka \\
\hline 7. & $H \cap N=\emptyset$ & przesłanka \\
\hline 8. & $B^{\prime} \cap K=\emptyset$ & przesłanka \\
\hline 9. & $R^{\prime} \cap D^{\prime}=\emptyset$ & przesłanka \\
\hline 10. & $M \cap L^{\prime}=\emptyset$ & przesłanka \\
\hline 11. & $E \cap K^{\prime}=\emptyset$ & $(\star): 1,5, \mathrm{C}$ \\
\hline 12. & $K^{\prime} \cap R=\emptyset$ & $(\star): 6,11, \mathrm{E}$ \\
\hline 13. & $R \cap B^{\prime}=\emptyset$ & $(\star): 8,12, \mathrm{~K}$ \\
\hline 14. & $R \cap M^{\prime}=\emptyset$ & $(\star): 4,13, \mathrm{~B}$ \\
\hline 15. & $M^{\prime} \cap D^{\prime}=\emptyset$ & $(\star): 9,14, \mathrm{R}$ \\
\hline 16. & $M^{\prime} \cap A^{\prime}=\emptyset$ & $(\star): 3,15, \mathrm{D}$ \\
\hline 17. & $A^{\prime} \cap L^{\prime}=\emptyset$ & $(\star): 10,16, \mathrm{M}$ \\
\hline 18. & $A^{\prime} \cap N^{\prime}=\emptyset$ & $(\star): 2,17, \mathrm{~L}$ \\
\hline 19. & $A^{\prime} \cap H=\emptyset$ & $(\star): 7,18, \mathrm{~N}$. \\
\hline
\end{tabular}

Wniosek z przesłanek 1.-10. można odczytać np.: I always avoid a kangaroo. Zachęcamy do samodzielnego narysowania drzewa dowodowego.

PRZYKŁAD 5.

- 1. No shark ever doubts that it is well fitted out.

- 2. A fish, that cannot dance a minuet, is contemptible.

- 3. No fish is quite certain that it is well fitted out, unless it has three rows of teeth.

- 4. All fishes, except sharks, are kind to children.

- 5. No heavy fish can dance a minuet.

- 6. A fish with three rows of teeth is not to be despised.

Znajdujemy nazwy występujące w tych zdaniach:

$$
\begin{aligned}
& A-\text { able to dance a minuet } \\
& B-\text { certain that he is well fitted out } \\
& C-\text { contemptible } \\
& D-\text { having three rows of teeth } \\
& E-\text { heavy } \\
& H-\text { kind to children } \\
& K-\text { sharks. }
\end{aligned}
$$

Znajdujemy schematy przesłanek:
1. $K \cap B^{\prime}=\emptyset$
2. $A^{\prime} \cap C^{\prime}=\emptyset$
3. $D^{\prime} \cap B=\emptyset$
4. $K^{\prime} \cap H^{\prime}=\emptyset$
5. $E \cap A=\emptyset$
6. $D \cap C=\emptyset$. 
Budujemy tabelę występowania nazw w przesłankach:

\begin{tabular}{|c|l|l|}
\hline Nazwa & Pozytywnie & Negatywnie \\
\hline$A$ & 5 & 2 \\
\hline$B$ & 3 & 1 \\
\hline$C$ & 6 & 2 \\
\hline$D$ & 6 & 3 \\
\hline$E$ & 5 & \\
\hline$H$ & & 4 \\
\hline$K$ & 1 & 4 \\
\hline
\end{tabular}

Tabela sugeruje, że wniosek będzie miał postać: $H^{\prime} \cap E=\emptyset$. Budujemy dowód rezolucyjny:

\begin{tabular}{|r|l|l|}
\hline 1. & $K \cap B^{\prime}=\emptyset$ & przesłanka \\
\hline 2. & $A^{\prime} \cap C^{\prime}=\emptyset$ & przesłanka \\
\hline 3. & $D^{\prime} \cap B=\emptyset$ & przesłanka \\
\hline 4. & $K^{\prime} \cap H^{\prime}=\emptyset$ & przesłanka \\
\hline 5. & $E \cap A=\emptyset$ & przesłanka \\
\hline 6. & $D \cap C=\emptyset$ & przesłanka \\
\hline 7. & $K \cap D^{\prime}=\emptyset$ & $(\star): 1,3, \mathrm{~B}$ \\
\hline 8. & $D^{\prime} \cap H^{\prime}=\emptyset$ & $(\star): 4,7, \mathrm{~K}$ \\
\hline 9. & $H^{\prime} \cap C=\emptyset$ & $(\star): 6,8, \mathrm{D}$ \\
\hline 10. & $H^{\prime} \cap A^{\prime}=\emptyset$ & $(\star): 2,9, \mathrm{C}$ \\
\hline 11. & $H^{\prime} \cap E=\emptyset$ & $(\star): 5,10, \mathrm{~A}$. \\
\hline
\end{tabular}

Wniosek z przesłanek 1.-6. można odczytać np.: No heavy fish is unkind to children. Drzewo dowodowe przedstawimy używając tylko numerów poszczególnych kroków:

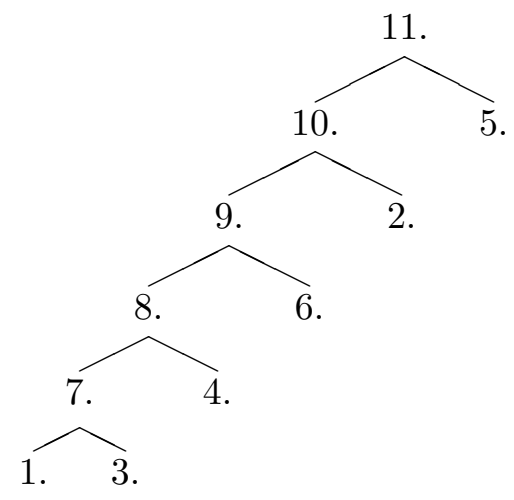

PRZYKŁAD 6.

- 1. Animals, that do not kick, are always unexcitable.

- 2. Donkeys have no horns.

- 3. A buffalo can always toss one over a gate.

- 4. No animals that kick are easy to swallow.

- 5. No hornless animal can toss one over a gate.

- 6. All animals are excitable, except buffaloes. 
Znajdujemy nazwy występujące w tych zdaniach:

$$
\begin{aligned}
& A-\text { able to toss one over the gate } \\
& B-\text { buffaloes } \\
& C-\text { donkeys } \\
& D-\quad \text { easy to swallow } \\
& E-\text { excitable } \\
& H-\text { horned } \\
& K-\quad \text { kicking. }
\end{aligned}
$$

Znajdujemy schematy przesłanek:

$$
\begin{array}{ll}
\text { 1. } & K^{\prime} \cap E=\emptyset \\
\text { 2. } & C \cap H=\emptyset \\
\text { 3. } & B \cap A^{\prime}=\emptyset \\
\text { 4. } & K \cap D=\emptyset \\
\text { 5. } & H^{\prime} \cap A=\emptyset \\
\text { 6. } & B^{\prime} \cap E^{\prime}=\emptyset .
\end{array}
$$

Budujemy tabelę występowania nazw w przesłankach:

\begin{tabular}{|c|l|l|}
\hline Nazwa & Pozytywnie & Negatywnie \\
\hline$A$ & 5 & 3 \\
\hline$B$ & 3 & 6 \\
\hline$C$ & 2 & \\
\hline$D$ & 4 & \\
\hline$E$ & 1 & 6 \\
\hline$H$ & 2 & 5 \\
\hline$K$ & 4 & 1 \\
\hline
\end{tabular}

Tabela sugeruje, że wniosek będzie miał postać: $D \cap C=\emptyset$. Budujemy dowód rezolucyjny:

\begin{tabular}{|r|l|l|}
\hline 1. & $K^{\prime} \cap E=\emptyset$ & przesłanka \\
\hline 2. & $C \cap H=\emptyset$ & przesłanka \\
\hline 3. & $B \cap A^{\prime}=\emptyset$ & przesłanka \\
\hline 4. & $K \cap D=\emptyset$ & przesłanka \\
\hline 5. & $H^{\prime} \cap A=\emptyset$ & przesłanka \\
\hline 6. & $B^{\prime} \cap E^{\prime}=\emptyset$ & przesłanka \\
\hline 7. & $E \cap D=\emptyset$ & $(\star): 1,4, \mathrm{~K}$ \\
\hline 8. & $D \cap B^{\prime}=\emptyset$ & $(\star): 6,7, \mathrm{E}$ \\
\hline 9. & $D \cap A^{\prime}=\emptyset$ & $(\star): 3,8, \mathrm{~B}$ \\
\hline 10. & $D \cap H^{\prime}=\emptyset$ & $(\star): 5,9, \mathrm{~A}$ \\
\hline 11. & $D \cap C=\emptyset$ & $(\star): 2,10, \mathrm{H}$. \\
\hline
\end{tabular}

Wniosek z przesłanek 1.-6. można odczytać np.: Donkey are not easy to swallow. Drzewo dowodowe przedstawimy używając tylko numerów poszczególnych kroków: 


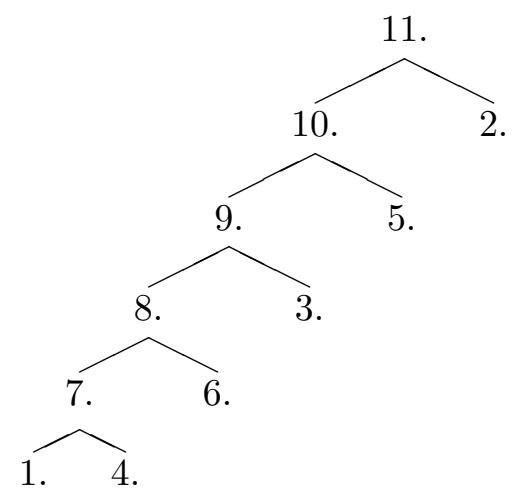

\subsection{Przykłady ukazujące bałamutność wskazówek heurystycznych}

Jak dotąd, wszystko było dobrze (jak mówił jegomość, mijając w locie piętro szóste, po wyskoczeniu $\mathrm{z}$ dwunastego piętra). I istotnie, reguła $(\star)$ jest poprawna. Jednak wskazówki heurystyczne Carrolla już takie nie są.

PRZYKeAD 7. The Library PRoblem.

Rozważmy układ następujących zdań kategorycznych, odnoszących się do książek w pewnej bibliotece:

- 1. All the old books are Greek.

- 2. All the quartos are bound.

- 3. None of the poets are old quartos.

Znajdujemy nazwy występujące w tych zdaniach:

$$
\begin{aligned}
& A-\text { bound } \\
& B-\text { Greek } \\
& C-\text { old } \\
& D-\text { poetry } \\
& E-\text { quartos. }
\end{aligned}
$$

Znajdujemy schematy przesłanek:

$$
\begin{array}{ll}
\text { 1. } & C \cap B^{\prime}=\emptyset \\
\text { 2. } & E \cap A^{\prime}=\emptyset \\
\text { 3. } & D \cap C \cap E=\emptyset .
\end{array}
$$

Budujemy tabelę występowania nazw w przesłankach:

\begin{tabular}{|c|l|l|}
\hline Nazwa & Pozytywnie & Negatywnie \\
\hline$A$ & & 2 \\
\hline$B$ & & 1 \\
\hline$C$ & 1,3 & \\
\hline$D$ & 3 & \\
\hline$E$ & 2,3 & \\
\hline
\end{tabular}

Widać, że na podstawie informacji z tej tabeli nie można wyeliminować, stosując $(\star)$, żadnej z rozważanych nazw. Carroll proponuje dołączyć dodatkową przesłankę, stwierdzającą, że suma wszystkich rozważanych nazw wyczerpuje całe uniwersum. W postaci zdania ogólno-przeczącego przesłanka ta przybiera postać: 
- 4. $A^{\prime} \cap B^{\prime} \cap C^{\prime} \cap D^{\prime} \cap E^{\prime}=\emptyset$.

Po tym uzupełnieniu rozszerzona tabela sugeruje, że wnioskiem będzie:

$$
A^{\prime} \cap B^{\prime}=\emptyset \text {. }
$$

Jest to jednak błedna sugestia. Kontrprzykład: niech $A=B=C=E=\{x\}, D=\{y\}, x \neq y$, a uniwersum to $\{x, y\}$. Wtedy 1.-4. są spełnione, ale $A^{\prime} \cap B^{\prime}=\{y\} \neq \emptyset$. Książka $x$ może być np. starym, greckim, oprawionym in quarto wydaniem Analityk Pierwszych (które, jak wiadomo, poezją nie są), a $y$ może być np. stosem luzem zebranych nowych kartek in folio, zawierającym elukubracje jakiegoś polskiego poety.

Korespondencja Carrolla z Johnem Cookiem Wilsonem dotycząca tego problemu zawiera m.in. uwagi Carrolla na temat sylogizmów, w których używa się zaprzeczeń iloczynów nazw, a także tego, co Carroll nazywa konkluzjami cześciowymi. Warto zwrócić uwagę, że Carroll posługuje się tu nie tylko prawami De Morgana, ale również prawami rozdzielności: dodawania względem mnożenia i mnożenia względem dodawania nazw.

Carroll zachęca też Wilsona do rozwiązania następującego łańcusznika: PRZYKŁAD 8.

- 1. $A \subseteq B \cup C \cup D$

- 2. $A \cap B \subseteq C \cup H$

- 3. $B \subseteq A \cup C \cup D$

- 4. $B \cap C \cap E \subseteq D$

- 5. $C \cap D \subseteq A \cup B$

- 6. $E \subseteq A \cup B \cup D$

- 7. $B \cap D \subseteq A \cup H$

- 8. $A \cap C \cap K \subseteq B$

- 9. $D \cap K \subseteq B \cup C$.

Powyższe zdania ogólno-twierdzące przekształcają się na następujące zdania ogólno-przeczące:

1. $A \cap B^{\prime} \cap C^{\prime} \cap D^{\prime}=\emptyset$

2. $A \cap B \cap C^{\prime} \cap H^{\prime}=\emptyset$

3. $A^{\prime} \cap B \cap C^{\prime} \cap D^{\prime}=\emptyset$

4. $B \cap C \cap D^{\prime} \cap E=\emptyset$

5. $A^{\prime} \cap B^{\prime} \cap C \cap D=\emptyset$

6. $A^{\prime} \cap B^{\prime} \cap D^{\prime} \cap E=\emptyset$

7. $A^{\prime} \cap B \cap D \cap H^{\prime}=\emptyset$

8. $A \cap B^{\prime} \cap C \cap K=\emptyset$

9. $B^{\prime} \cap C^{\prime} \cap D \cap K=\emptyset$.

Sporządzamy tabelę występowania nazw w przesłankach: 


\begin{tabular}{|c|l|l|}
\hline Nazwa & Pozytywnie & Negatywnie \\
\hline$A$ & $1,2,8$ & $3,5,6,7$ \\
\hline$B$ & $2,3,4,7$ & $1,5,6,8,9$ \\
\hline$C$ & $4,5,8$ & $1,2,3,9$ \\
\hline$D$ & $5,7,9$ & $1,3,4,6$ \\
\hline$E$ & 4,6 & \\
\hline$H$ & & 2,7 \\
\hline$K$ & 8,9 & \\
\hline
\end{tabular}

Tabela sugeruje, że wniosek będzie miał postać: $E \cap H^{\prime} \cap K=\emptyset$.

Proponujemy (jako pokutę) próbę znalezienia dowodu rezolucyjnego wprost. Nie może się ona udać, co wykazać można dowodem nie wprost. Wrócimy do tego przykładu nieco dalej.

\subsection{Problem (a może tylko ćwiczenie?)}

Tak więc, wskazówki heurystyczne Carrolla nie dają poprawnego algorytmu znajdowania konkluzji sorytu, jak widzieliśmy w poprzednich dwóch przykładach. Można jednak sensownie, jak nam się wydaje, pytać o klasę sorytów, dla których heurystyka Carrolla jest poprawna. Pytanie to można sformułować w sposób następujący.

Niech $\mathbb{S}$ będzie rodziną nullities o postaci:

$$
\begin{aligned}
& X^{11} \cap X^{12} \cap \ldots \cap X^{1 n_{1}}=\emptyset \\
& X^{21} \cap X^{22} \cap \ldots \cap X^{2 n_{2}}=\emptyset \\
& \ldots \\
& X^{m 1} \cap X^{m 2} \cap \ldots \cap X^{m n_{m}}=\emptyset
\end{aligned}
$$

gdzie $\mathbf{R}(\mathbb{S})$, zbiór wszystkich retinends dla $\mathbb{S}$, jest niepusty. Postawmy problem następujący:

$(\star \star)$ Znaleźć warunki konieczne i wystarczające, przy których nullity

$$
\bigcap \mathbf{R}(\mathbb{S})=\emptyset
$$

wynika logicznie (na gruncie rachunku zbiorów) ze zbioru nullities $\mathbb{S}$.

Problem powyższy można także sformułować w terminach pokryć uniwersum $U$, przez proste zastosowanie praw De Morgana.

Rozwiązanie problemu $(\star \star)$ dałoby nam twierdzenie o pełności dla The Method of Underscoring Carrolla. Chociaż omówiona wyżej heurystyka Carrolla nie jest trafna dla wszelkich sorytów, możemy pytać, dla jakich sorytów jest ona trafna.

Zauważmy przy tym, że rozwiązanie problemu $(\star \star)$ powinno zostać podane w aparaturze pojęciowej algebry zbiorów (jeśli chcielibyśmy pozostać wierni metodom stosowanym przez samego Lewisa Carrolla).

\section{3 „Metoda drzew" Carrolla}

16 lipca 1894 roku Carroll zanotował w swoim Diary:

Today has proved to be an epoch in my Logical work. It occurred to me to try a complex Sorites by the method I have been using for ascertaining what cells, if any, survive for possible occupation when certain nullities are given. I took one of 40 premisses, „pairs within pairs" \& many bars, \& worked it like a genealogy, each term providing all its descendents. It came out beatifully, \& much shorter than the method I have used hitherto - I think of calling it the „Genealogical Method”. 
Metodę tę nazywał Carroll również metodq drzew (The Method of Trees). Istota tej metody polega na przypuszczeniu nie wprost, że wniosek jest fałszywy i otrzymaniu sprzeczności z tego przypuszczenia, co w konsekwencji nakazuje owo przypuszczenie odrzucić. Pokażemy na paru przykładach, jak Carroll stosował tę metodę.

PRZYKŁAD 9. DRZEWO BEZ ROZGAŁĘZIEŃ.

Rozważmy układ ośmiu zdań kategorycznych:

$$
\begin{array}{ll}
\text { 1. } & D^{\prime} \cap N^{\prime} \cap M^{\prime}=\emptyset \\
\text { 2. } & K \cap A^{\prime} \cap C^{\prime}=\emptyset \\
\text { 3. } & L \cap E \cap M=\emptyset \\
\text { 4. } & D \cap H \cap K^{\prime}=\emptyset \\
\text { 5. } & H^{\prime} \cap L \cap A^{\prime}=\emptyset \\
\text { 6. } & H \cap M^{\prime} \cap B^{\prime}=\emptyset \\
\text { 7. } & A^{\prime} \cap B \cap N=\emptyset \\
\text { 8. } & A \cap M^{\prime} \cap E=\emptyset .
\end{array}
$$

Budujemy tabelę występowania nazw w przesłankach:

\begin{tabular}{|c|l|l|}
\hline Nazwa & Pozytywnie & Negatywnie \\
\hline$A$ & 8 & $2,5,7$ \\
\hline$B$ & 7 & 6 \\
\hline$C$ & & 2 \\
\hline$D$ & 4 & 1 \\
\hline$E$ & 3,8 & \\
\hline$H$ & 4,6 & 5 \\
\hline$K$ & 2 & 4 \\
\hline$L$ & 3,5 & \\
\hline$M$ & 3 & $1,6,8$ \\
\hline$N$ & 7 & 1 \\
\hline
\end{tabular}

Tabela sugeruje, że wniosek powinien mieć postać: $C^{\prime} \cap E \cap L=\emptyset$. Ponieważ siedem nazw będzie wyeliminowanych, więc dowód rezolucyjny składa się z 15 kroków (8 przesłanek oraz 7 zastosowań $(\star)$ ). Można przedstawić też dowód nie wprost, jeśli nie krótszy (w tym akurat przypadku), to mający ogólniejszy walor. Przypuśćmy mianowicie, że $C^{\prime} \cap E \cap L=\emptyset$ nie zachodzi. Wtedy

$$
\text { (†) } C^{\prime} \cap E \cap L \neq \emptyset
$$

tj. zbiór $C^{\prime} \cap E \cap L$ zawiera jakieś elementy. Pokażemy, że przypuszczenie to prowadzi do sprzeczności, a więc że należy je odrzucić.

Niech $x \in C^{\prime} \cap E \cap L$. Ponieważ $x \in E \cap L$, a na mocy przesłanki 3. $(L \cap E) \cap M=\emptyset$, więc $x \notin M$, czyli $x \in M^{\prime}$. Tak więc, $x \in E \cap M^{\prime}$. Stąd, ponieważ $A \cap\left(M^{\prime} \cap E\right)=\emptyset$ (przesłanka 8.), więc $x \notin A$, czyli $x \in A^{\prime}$. Skoro $x \in C^{\prime}$ (na mocy (†)) oraz $x \in A^{\prime}$, więc $x \notin K$ (na mocy przesłanki 2.: $K \cap\left(A^{\prime} \cap C^{\prime}\right)=\emptyset$ ). A zatem $x \in K^{\prime}$. Skoro $x \in E$ oraz $x \in A^{\prime}$, to (na mocy przesłanki 5.: $\left.H^{\prime} \cap\left(L \cap A^{\prime}\right)=\emptyset\right) x \notin H^{\prime}$, czyli $x \in H$. Skoro $x \in H$ i $x \in K^{\prime}$, to (na mocy przesłanki 4.: $\left.D \cap\left(H \cap K^{\prime}\right)=\emptyset\right) x \notin D$, czyli $x \in D^{\prime}$. Skoro $x \in M^{\prime}$ oraz $x \in H$, to (na mocy przesłanki 6.: $\left.\left(H \cap M^{\prime}\right) \cap B^{\prime}=\emptyset\right) x \notin B^{\prime}$, czyli $x \in B$. Skoro $x \in D^{\prime}$ oraz $x \in M^{\prime}$, to (na mocy przesłanki 1.: $\left.\left(D^{\prime} \cap M^{\prime}\right) \cap N^{\prime}=\emptyset\right) x \notin N^{\prime}$, czyli $x \in N$. Wreszcie, skoro $x \in A^{\prime}$ oraz $x \in B$, to (na mocy przesłanki 7.: $\left.\left(A^{\prime} \cap B\right) \cap N=\emptyset\right) x \notin N$, czyli $x \in N^{\prime}$. Ponieważ $N \cap N^{\prime}=\emptyset$, otrzymaliśmy sprzeczność: $x \in N$ oraz $x \in N^{\prime}$. Musimy więc odrzucić przypuszczenie $(\dagger)$ i tym samym otrzymujemy wniosek $C^{\prime} \cap E \cap L=\emptyset$.

Jak widać, był to dowód dla Humanistek, które lubią, gdy wypowiadamy się pełnymi zdaniami, niczego nie opuszczając. Spróbujmy teraz przedstawić ten dowód w nieco skróconej (i chyba bardziej przejrzystej) postaci: 

1. $D^{\prime} \cap N^{\prime} \cap M^{\prime}=\emptyset \quad$ przesłanka
2. $K \cap A^{\prime} \cap C^{\prime}=\emptyset \quad$ przesłanka
3. $L \cap E \cap M=\emptyset$ przesłanka
4. $D \cap H \cap K^{\prime}=\emptyset$ przesłanka
5. $H^{\prime} \cap L \cap A^{\prime}=\emptyset \quad$ przesłanka
6. $H \cap M^{\prime} \cap B^{\prime}=\emptyset \quad$ przesłanka
7. $A^{\prime} \cap B \cap N=\emptyset$ przesłanka
8. $A \cap M^{\prime} \cap E=\emptyset$ przesłanka
9. $x \in C^{\prime} \cap E \cap L \quad$ z.d.n.
10. $x \in M^{\prime} \quad 3,9$
11. $x \in A^{\prime} \quad 8,9,10$
12. $x \in K^{\prime} \quad 2,9,11$
13. $x \in H \quad 5,9,11$
14. $x \in D^{\prime} \quad 4,12,13$
15. $x \in B \quad 6,10,13$
16. $x \in N \quad 1,10,14$
17. $x \in N^{\prime} \quad 7,11,15$
18. $\perp \quad$ SPRZECZNOŚĆ: 16,17 .

Ostatecznie, udowodniliśmy, że $C^{\prime} \cap E \cap L=\emptyset$. W formie ogólno-twierdzącej zdanie to przyjmuje np. postać: $(E \cap L) \subseteq C$.

PRZYKŁAD 10. DRZEWO Z ROZGAŁĘZIENIAMI.

Rozważmy siedem zdań kategorycznych:
1. $H \cap M \cap K=\emptyset$
2. $D^{\prime} \cap E^{\prime} \cap C^{\prime}=\emptyset$
3. $H \cap K^{\prime} \cap A^{\prime}=\emptyset$
4. $B \cap L \cap H^{\prime}=\emptyset$
5. $C \cap K \cap M^{\prime}=\emptyset$
6. $H \cap C^{\prime} \cap E=\emptyset$
7. $B \cap A \cap K^{\prime}=\emptyset$.

Budujemy tabelę występowania nazw w przesłankach:

\begin{tabular}{|c|l|l|}
\hline Nazwa & Pozytywnie & Negatywnie \\
\hline$A$ & 7 & 3 \\
\hline$B$ & 4,7 & \\
\hline$C$ & 5 & 2,6 \\
\hline$D$ & & 2 \\
\hline$E$ & 6 & 2 \\
\hline$H$ & $1,3,6$ & 4 \\
\hline$K$ & 1,5 & 3,7 \\
\hline$L$ & 4 & \\
\hline$M$ & 1 & 5 \\
\hline
\end{tabular}

Tabela sugeruje, że wniosek powinien mieć postać $B \cap D^{\prime} \cap L=\emptyset$. Przypuśćmy, dla dowodu nie wprost, że:

$$
\text { (†) } B \cap D^{\prime} \cap L \neq \emptyset .
$$

Pokażemy, że przypuszczenie to prowadzi do sprzeczności, a więc że należy je odrzucić.

Niech $x \in B \cap D^{\prime} \cap L$. Wtedy, skoro $x \in B \cap L$, więc na mocy przesłanki 4. $x \notin H^{\prime}$, czyli $x \in H$. Skoro $x \in H$ oraz, na mocy przesłanki $1 . H \cap M \cap K=\emptyset$, to $x \notin M \cap K$. Jednak nie można 
dalej prowadzić dowodu w sposób liniowy, trzeba rozumowanie rozgałęzić, ponieważ $x \notin M \cap K$ oznacza, że zachodzi alternatywa:

- (1) $x \notin K$, czyli $x \in K^{\prime} \quad$ lub

- (2) $x \notin M$, czyli $x \in M^{\prime}$.

Każdy z przypadków (1) i (2) należy teraz rozpatrzyć oddzielnie. Dziś jest to dla nas oczywiste: odwołujemy się do jednego z praw De Morgana. Carroll sformułował samodzielnie to prawo (w liście z 11 listopada 1896 roku do Johna Cooka Wilsona), nie powołując się na inne publikacje z tego, co dziś nazywamy nurtem algebraicznym w logice XIX wieku. Na marginesie dodajmy, że prawa znane dziś pod nazwą praw De Morgana były znane już logikom średniowiecznym. Wracamy do dowodu. Carroll konstatuje w tym miejscu, że:

- (1') do warunku (1) można dodać warunek $x \in M$, co jednak nie przyniesie żadnej korzyści, ponieważ $M$ występowała tylko w przesłance 1., którą już wykorzystaliśmy;

- (2’) do warunku (2) można dodać warunek $x \in K$, co być może okaże się użyteczne, jako iż $K$ występuje w dotąd nie rozważanej przesłance 5 .

Za uzasadnienie (1') oraz (2') Carroll uważa sformułowaną przez siebie regute:

Thus, if we found a Premiss proving that the Thing could not have the Pair of Attributes $b^{\prime} c$, we might say it must have $b$ or $c^{\prime}$. And we might afterwards tack on, at pleasure, either $c$ to $b$, making the two headings $b c$ and $c^{\prime}$, or $b^{\prime}$ to $c^{\prime}$, making them $b$ and $c^{\prime} b^{\prime}$.

Carroll odwołuje się tutaj zatem do obserwacji, którą w dzisiejszej notacji zapisujemy w postaci:

$$
(A \cap B)^{\prime}=\left(A^{\prime} \cap B\right) \cup\left(A \cap B^{\prime}\right) \cup\left(A^{\prime} \cap B^{\prime}\right) .
$$

Można przypuszczać, że obserwację tę zawdzięcza analizie swoich diagramów dla zbiorów.

(1) Skoro $x \in K^{\prime}$, to z $x \in H$ oraz z przesłanki 3. otrzymujemy: $x \notin A^{\prime}$, czyli $x \in A$. Skoro $x \in K^{\prime}$ oraz $x \in A$, to z przesłanki 7. otrzymujemy, że $x \notin A$. A to oznacza sprzeczność: nie może być jednocześnie $x \in A$ oraz $x \notin A$.

(2) Skoro $x \in M^{\prime}$, to na mocy (2') oraz przesłanki 5. otrzymujemy, że $x \notin C$, czyli $x \in C^{\prime}$. Skoro $x \in D^{\prime}$ (przypuszczenie $(\ddagger)$ ) oraz $x \in C^{\prime}$, to na mocy przesłanki 2. mamy $x \notin E^{\prime}$, czyli $x \in E$. Wreszcie, skoro $x \in H$ oraz $x \in C^{\prime}$, to na mocy przesłanki 6. mamy $x \notin E$. A to oznacza sprzeczność: nie może być jednocześnie $x \in E$ oraz $x \notin E$.

Pokazaliśmy zatem, że każda z możliwości (1) i (2) prowadzi do sprzeczności. Przypuszczenie ( ) należy więc odrzucić. Ostatecznie otrzymujemy:

$$
B \cap D^{\prime} \cap L=\emptyset .
$$

Przekształcając to na równoważne mu zdanie ogólno-twierdzące (jeśli ktoś takie woli) dostajemy: $(B \cap L) \subseteq D$.

Carroll rozważa również o wiele bardziej skomplikowane dowody nie wprost, o złożonych drzewach dowodowych.

A jak radził sobie Carroll z przypadkami, gdy przypuszczenie dowodu nie wprost nie prowadziło do sprzeczności? Przykład znajdujemy w liście Carrolla do Johna Cooka Wilsona z 18 listopada 1896 roku:

PRZYKEAD 8. PONOWNIE.

Przypomnijmy dziewięć zdań kategorycznych z przykładu 8.: 
1. $A \cap B^{\prime} \cap C^{\prime} \cap D^{\prime}=\emptyset$

2. $A \cap B \cap C^{\prime} \cap H^{\prime}=\emptyset$

3. $B \cap A^{\prime} \cap C^{\prime} \cap D^{\prime}=\emptyset$

4. $B \cap C \cap E \cap D^{\prime}=\emptyset$

5. $C \cap D \cap A^{\prime} \cap B^{\prime}=\emptyset$

6. $E \cap A^{\prime} \cap B^{\prime} \cap D^{\prime}=\emptyset$

7. $B \cap D \cap A^{\prime} \cap H^{\prime}=\emptyset$

8. $A \cap C \cap K \cap B^{\prime}=\emptyset$

9. $D \cap K \cap B^{\prime} \cap C^{\prime}=\emptyset$.

Budujemy tabelę występowania nazw w przesłankach:

\begin{tabular}{|c|l|l|}
\hline Nazwa & Pozytywnie & Negatywnie \\
\hline$A$ & $1,2,8$ & $3,5,6,7$ \\
\hline$B$ & $2,3,4,7$ & $1,5,6,8,9$ \\
\hline$C$ & $4,5,8$ & $1,2,3,9$ \\
\hline$D$ & $5,7,9$ & $1,3,4,6$ \\
\hline$E$ & 4,6 & \\
\hline$H$ & & 2,7 \\
\hline$K$ & 8,9 & \\
\hline
\end{tabular}

Tabela ta sugeruje, że wniosek powinien mieć postać: $E \cap H^{\prime} \cap K=\emptyset$. Pokażemy, że jest to błedna sugestia. Oznacza to m.in. to, że $\mathrm{w}$ logice nie wolno kierować sie wytacznie sugestiami każda teza musi posiadać wyraźny, nie budzący wątpliwości dowód. Tak też zawsze postępował Lewis Carroll — nigdy nie ograniczał się do sporządzenia wykazu atrybutów oraz podania konkluzji sugerowanej przez tabelę pozytywnych i negatywnych wystąpień nazw; za każdym razem sugestie otrzymane w wyniku zastosowania swojej heurystyki sprawdzat. Początkowo używał dowodów rezolucyjnych, a gdy dostrzegł, że metoda sugerowana przez heurystykę nie jest w ogólności poprawna, zaczął stosować dowody apagogiczne i w ten sposób uzyskał prototyp metody tablic analitycznych.

Przypuśćmy, dla dowodu nie wprost, że:

$$
E \cap H^{\prime} \cap K \neq \emptyset \text {. }
$$

Niech $x \in E \cap H^{\prime} \cap K$. Skoro $x \in E$, to, na mocy przesłanki 4., otrzymujemy: $x \notin B \cap\left(C \cap D^{\prime}\right)$, a więc zachodzi alternatywa:

- (1) $x \in B^{\prime}$ lub

- (2) $x \in\left(C \cap D^{\prime}\right)^{\prime}$.

Rozważmy najpierw przypadek (1). Skoro $x \in E$ oraz $x \in B^{\prime}$, to, na mocy przesłanki 6. $x \notin$ $\left(A^{\prime} \cap D^{\prime}\right)$, a więc zachodzi alternatywa:

- (1.1.) $x \in A$ lub

- (1.2.) $x \in D$.

Rozpatrzmy przypadek (1.1.). Skoro $x \in A, x \in B^{\prime}$ oraz $x \in K$, to, na mocy przesłanki 8., $x \notin C$, czyli $x \in C^{\prime}$. Z $x \in A, x \in B^{\prime}$ oraz $x \in C^{\prime}$, na mocy przesłanki 1 . mamy: $x \notin D^{\prime}$, czyli $x \in D$. Wreszcie, skoro $x \in K, x \in B^{\prime}$ oraz $x \in C^{\prime}$, to, na mocy przesłanki 1., mamy: $x \notin D$. Otrzymaliśmy zatem sprzeczność: $x \in D$ i $x \notin D$. Przypadek (1.1.) został wykluczony.

Wracamy do przypadku (1.2.). Carroll czyni w tym miejscu dodatkowe założenie, że $x \in A^{\prime}$, uzasadniając je powołaniem się na przytoczoną wyżej regute. Skoro $x \in B^{\prime}, x \in D$ oraz $x \in A^{\prime}$, 
to, na mocy przesłanki 5., $x \notin C$, czyli $x \in C^{\prime}$. Skoro $x \in K, x \in B^{\prime}$ oraz $x \in D$, to, na mocy przesłanki 9., $x \notin C^{\prime}$. Otrzymaliśmy sprzeczność: $x \in C^{\prime}$ i $x \notin C^{\prime}$. Przypadek (1.2.) został więc wykluczony.

Wracamy do przypadku (2). Znowu, powołując się na cytowaną regułe, Carroll przyjmuje założenie, że $x \in B$. Skoro $x \in\left(C \cap D^{\prime}\right)^{\prime}$, to zachodzi alternatywa:

- (2.1.) $x \in C^{\prime}$ (oraz $x \in B$ ) lub

- (2.2.) $x \in D($ oraz $x \in B)$.

Rozpatrzmy przypadek (2.1.). Skoro $x \in H^{\prime}, x \in C^{\prime}$ oraz $x \in B$, to, na mocy przesłanki 2., $x \notin A$, czyli $x \in A^{\prime}$. Skoro $x \in B, x \in A^{\prime}$ oraz $x \in C^{\prime}$, to na mocy przesłanki 3., $x \notin D^{\prime}$, czyli $x \in D$. Wreszcie, skoro $x \in H^{\prime}, x \in B$ oraz $x \in A^{\prime}$, to, na mocy przesłanki 7., $x \notin D$ i otrzymujemy sprzeczność z $x \in D$. Tak więc, przypadek (2.1.) został wykluczony.

Rozpatrzmy przypadek (2.2.). Skoro $x \in H^{\prime}, x \in B$ oraz $x \in D$, to, na mocy przesłanki 7. mamy: $x \notin A^{\prime}$, czyli $x \in A$. Nie możemy skorzystać z żadnej przesłanki, aby wykluczyć przypadek (2.2.). Tak więc, przypuszczenie dowodu nie wprost zostało potwierdzone, a to oznacza, że zdanie $E \cap H^{\prime} \cap$ $K=\emptyset$ nie jest konsekwencją założeń 1.-9. Sytuacja, że przesłanki łańcusznika są prawdziwe, a jego wniosek fałszywy nie została wykluczona. Może istnieć przedmiot $x$ taki, że $x \in E \cap H^{\prime} \cap K$ oraz wszystkie przesłanki 1.-9. są prawdziwe. $\mathrm{Z}$ analizy przypadku (2.2.) widać, że dla takiego $x$ mamy: $x \in A \cap B \cap C \cap D$.

Analiza przypadku (2.2.) pokazuje ponadto, jakie wnioski wynikaja logicznie z podanego układu przesłanek. Otóż jest to np. każde ze zdań:

- $E \cap H^{\prime} \cap K \cap A^{\prime}=\emptyset$

- $E \cap H^{\prime} \cap K \cap B^{\prime}=\emptyset$

- $E \cap H^{\prime} \cap K \cap C^{\prime}=\emptyset$

- $E \cap H^{\prime} \cap K \cap D^{\prime}=\emptyset$.

Jest tak, ponieważ z każdego z tych zdań, łącznie z rozważanymi przesłankami, otrzymać można sprzeczność w przypadku (2.2.), a więc przypadek ten wykluczyć.

Dalej, analiza przypadku (2.2.) pokazuje także, że dołączenie do 1.-9. każdej z osobna z przesłanek 10.-13:

- $10 . A=\emptyset$

- $11 . B=\emptyset$

- 12. $C=\emptyset$

- $13 . D=\emptyset$

powoduje, że z takiego dziesięcioelementowego zbioru przesłanek wynika logicznie $E \cap H^{\prime} \cap K=\emptyset$.

Oczywiście takie modyfikacje „łamią symetrię” w przykładzie Carrolla. Celem analizy tego przykładu było zresztą co innego, a mianowicie pokazanie, że metoda drzew pozwala orzec, że jakiś wniosek nie wynika logicznie z ustalonego zbioru przesłanek.

Uwaga 6. Oczywiście Carroll nie używa w swoim dowodzie teoriomnogościowego symbolu $\in$ : posługuje się wyłącznie algebrą zbiorów.

Powyższy przykład nie pokazuje (wbrew temu, co twierdził John Cook Wilson we wspomnianej korespondencji) klęski metody Carrolla badania łańcuszników. Jest całkiem odwrotnie. Można przypuszczać, że Carroll, po odkryciu swojej „metody drzew”, sformułowałby — gdyby Los dał mu więcej czasu — reguły rządzące tego typu dowodami apagogicznymi, przynajmniej dla sylogistyki (z dowolnymi kombinacjami Boolowskimi nazw). Mniej uzasadnione jest przypuszczenie, że mógłby rozszerzyć tę metodę np. na rachunek zdań. 


\section{Uwagi metalogiczne i historyczne}

Dodajmy jeszcze kilka uwag, które mamy nadzieję rozwinąć w innym miejscu, na przykład w przygotowywanym do druku skrypcie Tablice analityczne.

\subsection{Uwagi metalogiczne}

Jak widzieliśmy w przykładach 7. oraz 8., metody rozwiązywania łańcuszników nie można sprowadzić do zwykłej rezolucji liniowej. Natomiast metoda nie wprost (,metoda drzew”) ma walor ogólny: można ja stosować do dowolnego zbioru przesłanek (tu: do dowolnych zdań kategorycznych), mając pewność, że wychodząc od zaprzeczenia konkluzji dojdzie się do jednego z następujących, wykluczających się wzajem przypadków:

- (1) przesłanki i zaprzeczona konkluzja prowadzą do sprzeczności; wtedy konkluzja wynika logicznie z przesłanek;

- (2) przesłanki i zaprzeczona konkluzja nie prowadzą do sprzeczności; wtedy konkluzja nie wynika logicznie z przesłanek.

Przypomnijmy, że monadyczny Klasyczny Rachunek Predykatów jest rozstrzygalny (jak wiadomo już z wyniku Löwenheima z 1915 roku), a ponieważ całość problematyki, którą zajmował się Lewis Carroll przy rozwiązywaniu swoich sorytów daje się oczywiście przedstawić w monadycznym Klasycznym Rachunku Predykatów, więc całość ta jest również rozstrzygalna.

Oczywiście, osobno należy podać dowód poprawności „metody drzew” Carrolla, tj. wykazać, że jest ona trafna oraz petna. Dowód taki istnieje dla Klasycznego Rachunku Predykatów, a więc obejmuje również wszelkie wnioskowania z użyciem zdań kategorycznych. Można też zbudować osobny rachunek sylogistyczny z metodą drzew i dowieść jej poprawności — zob. np. Simons 1989.

Czy materiał zgromadzony w Symbolic Logic jest oparty na jakimś systemie logicznym? Jeśli tak, to na jakim? Jak zauważa Bartley, Carroll stosował metodę tablic dla funkcji prawdziwościowych już w 1894 roku, a więc wcześniej od propozycji Emila Posta oraz Ludwiga Wittgensteina. Oczywiście metodę tablic stosowano też wcześniej — używał jej np. Peirce w 1885 roku oraz Schröder w 1891 roku. Klasyczna sylogistyka jest w całości zawarta w algebraicznym ujęciu Carrolla przedstawionym w Symbolic Logic z 1896 roku. Jak widzieliśmy wyżej, Carroll stosował też apagogiczną metodę drzew, której początek datuje się zwykle od prac Betha, Hintikki, Kangera i Schütte'go z końca lat pięćdziesiątych XX wieku, a której rozwinięcia dokonali m.in. Smullyan, Lis i Jeffrey. Jak już wspominaliśmy, obecnie metoda ta jest jedną z ważniejszych metod dowodowych stosowanych w praktyce (np. w automatycznym dowodzeniu twierdzeń).

\subsection{Uwagi historyczne}

Dzieło logiczne Carrolla powstało pod koniec XIX wieku, w okresie, gdy rozwijał się całkiem nowy nurt w logice: podejście algebraiczne zapoczątkowane pracami George'a Boole'a oraz Augustusa De Morgana, a mające swoją kulminację w dziele Ernsta Schrödera. W wysiłku tym uczestniczyli m.in.: MacColl, Peirce, Jevons, Venn, by wymienić tylko kilka znakomitości.

Carroll znał dokonania pracujących na tym polu. Jego Symbolic Logic nie jest jednak monografią pisaną z zamiarem tworzenia systemu logicznego. Pierwszoplanowy cel był natomiast dydaktyczny: książka miała służyć popularyzacji logiki. I cel ten został osiągnięty: do dzisiaj tekst ten służy jako pomoc dydaktyczna, z upodobaniem wykorzystywana przez wielu wykładowców. Bez wątpliwości, ten sukces edukacyjny jest po części wynikiem literackiego talentu autora.

Część pierwsza Symbolic Logic ma bardzo elementarny charakter, stanowi przystępne wprowadzenie do sylogistyki klasycznej. Zawiera też omówienie metody diagramów Carrolla oraz jego metody underscoring (prototypu dzisiejszej rezolucji liniowej). 
Odnaleziona po siedemdziesięciu latach przez W.W. Bartleya część druga zawiera problemy bardziej zaawansowane (np. zdania kategoryczne ze złożonymi podmiotami i orzecznikami) oraz wprowadza metodę drzew. Sześć rozdziałów tej części nie zostało odnalezionych.

Carroll zapowiadał część trzecią: Part III: Transcendental, do której miał — wedle jego słów sporo notatek. O ile wiadomo, część ta nie powstała w wersji gotowej do druku. Dwa z zapowiadanych rozdziałów tej części nosić miały tytuły: Analysis of a Proposition into its Elements oraz The Theory of Inference.

Niniejszy tekst nie przedstawia żadnych głębokich odkryć, ani natury logicznej, ani historycznej. O tym, że Lewis Carroll był prekursorem metody tablic analitycznych wiadomo od 1977 roku, kiedy to W.W. Bartley opublikował odnalezione po ponad siedemdziesięciu latach fragmenty części II Symbolic logic. Fakt prekursorstwa Carrolla na tym polu nie jest jednak, naszym zdaniem, należycie doceniony. I temu między innymi ma służyć niniejszy tekst: wskazaniu, iż Lewis Carroll nie tylko umiał znakomicie spożytkować swój talent literacki w przygotowaniu oryginalnego podręcznika logiki, ale że powinien być także doceniany jako logik, który pewne metody dowodowe odkrył o wiele wcześniej niż inni.

Jak wiadomo, po śmierci Carrolla olbrzymia liczba jego pieczołowicie zbieranych i skatagolowanych notatek została

\section{S P A L O N A.}




\section{Bibliografia}

Abeles, F. 1990. Lewis Carroll's Method of Trees: Its Origin in „Studies in Logic”. Modern Logic 1, 25-35.

Abeles, F. 2005. Lewis Carroll's Formal Logic. History and Philosophy of Logic 26, 33-46.

Bartley, W.W., III. 1977. Lewis Carroll's Symbolic Logic. Clarkson N. Potter, New York.

Carroll, L. 1896. Symbolic Logic. Macmillan, London.

Carroll, L. 1994. El juego de la lógica y otros escritos. El Libro de Bolsillo, Madrid.

Coquand, Th. 2000. Lewis Carroll, Gentzen and Entailment Relations.

http://en.scientificcommons.org/265225

Crisler, V. 1999. Logical Algebra: Part 2. The Sorites.

http://vernerable.tripod.com/logic1.htm

Grattan-Guiness, I. 2000. The Search for Mathematical Roots, 1870-1940. Logics, Set Theories and the Foundation of Mathematics from Cantor through Russell to Gödel. Princeton University Press, Princeton/Oxford.

Jussien, N. Programmation Logique — TP noté. Les sorites de Lewis Carroll.

http://www.emn.fr/X-info/jussien/prolog/data/tp-sorites-prolog.pdf

Peckhaus, V. 1999. 19th Century Logic Between Philosophy and Mathematics. Bulletin of Symbolic Logic 5, $433-450$.

Simons, P. 1989. Tree Proofs for Syllogistic. Studia Logica 48, 539-554. 